С. А. Жваненко,

к. е.н., доцент кафедри економіки, підприємництва та фінансів,

Бердянський державний педагогічний університет

ORCID ID: 0000-0001-6790-3317

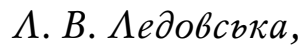
магістрант кафедри економіки, підприємничтва та фінансів, Бердянський державний педагогічний університет

ORCID ID: 0000-0001-5134-5592

DOI: $10.32702 / 2306-6814.2021 .5 .40$

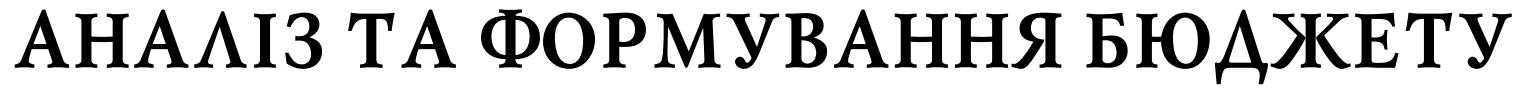 ЗАПОРІЗЬКОГО РЕГІОНУ
}

\author{
S. Zhvanenko, \\ $\mathrm{PhD}$ in Economics, Associate Professor of the Department of Economics, \\ Entrepreneurship and Finance, Berdyansk State Pedagogical University \\ L. Ledovska, \\ Master's student of the Department of Economics, Entrepreneurship and Finance, \\ Berdyansk State Pedagogical University
}

\section{ANALYSIS AND BUDGET FORMATION ZAPORIZHZYA REGION}

Місцеве бюджетування дає змогу планувати та керувати своїми фінансовими ресурсами для підтримки реалізації різних програм та проектів, які найкраще сприяють розвитку окремого регіону. У статті здійснено аналіз ефективності формування та виконання бюджетуна прикладі Запорізької області протягом трьох років, визначено його основі складові та основні джерела формування. Проаналізовано динаміку основних макроекономічних показників соціального та економічного розвитку України, здійснено аналіз обсягу доходів обласних бюджетів та їх населення. Проаналізовано як впливає підвищення ціни на рівень та якість життя населення, їх економічну захищеність. На основі проведеного аналізу було запропоновано основні заходи щодо підвищення ефективності бюджетних витрат, проаналізовано їх вплив на складові ефективності бюджетних витрат та визначено основні етапи їх реалізації.

Budgeting is a crucial task in the distribution of income and borrowed funds to achieve economic and social goals in the country. It also involves managing revenues and expenditures in a way that creates the greatest economic impact from production to delivery of goods and services, while maintaining a sound fiscal position. Local budgeting is important because it allows you to plan and manage your financial resources to support the implementation of various programs and projects that best contribute to the development of a particular region. At the expense of the budget, local governments can set priorities and implement programs and policies within the limits of their financial capacity, dictated by economic conditions. Legislative budgetary rules allow minimizing the dependence of the local budget system on price volatility in the domestic market of goods and services, increase the importance of long-term financial forecasting of revenues and expenditures and form the necessary amounts of sovereign funds of local budgets. Budget revenue planning is an important component of the budget and tax management system, the role of which has until recently been underestimated by both scholars and practitioners. Underestimation of the tax planning process 
in the organization of local finances and determination of budget revenues most often led to imbalances in tax policy and as a consequence in the management of budget flows. The article analyzes the effectiveness of budget formation and execution on the example of Zaporizhia region for three years, identifies its components and main sources of formation. The dynamics of the main macroeconomic indicators of social and economic development of Ukraine is analyzed, the analysis of the volume of incomes of regional budgets and their population is carried out. It is analyzed how the price increase affects the level and quality of life of the population, their economic security. Based on the analysis, the main measures to improve the efficiency of budget expenditures were proposed, their impact on the components of the efficiency of budget expenditures was analyzed and the main stages of their implementation were identified.

Ключові слова: бюджет, місиеъе бюджетування, планування, система упраљління, фрінансове прогнозування.

Key words: budget, local budgeting, planning, management system, financial forecasting.

\section{ПОСТАНОВКА ПРОБ АЕМИ}

Бюджетування - це вирішальне завдання розподілу доходів та позикових коштів для досягнення економічних та соціальних цілей в країні. Місцеве бюджетування є важливим, оскільки дає змогу планувати та керувати своїми фрінансовими ресурсами для підтримки реалізації різних програм та проектів, які найкраще сприяють розвитку окремого регіону. За рахунок бюджету органи місцевого самоврядування можуть визначати пріоритети та вводити в дію програми та політику в межах обмежень своєї фрінансової спроможності, продиктованих економічними умовами. Законодавчо закріплені бюджетні правила дозволяють мінімізувати за-

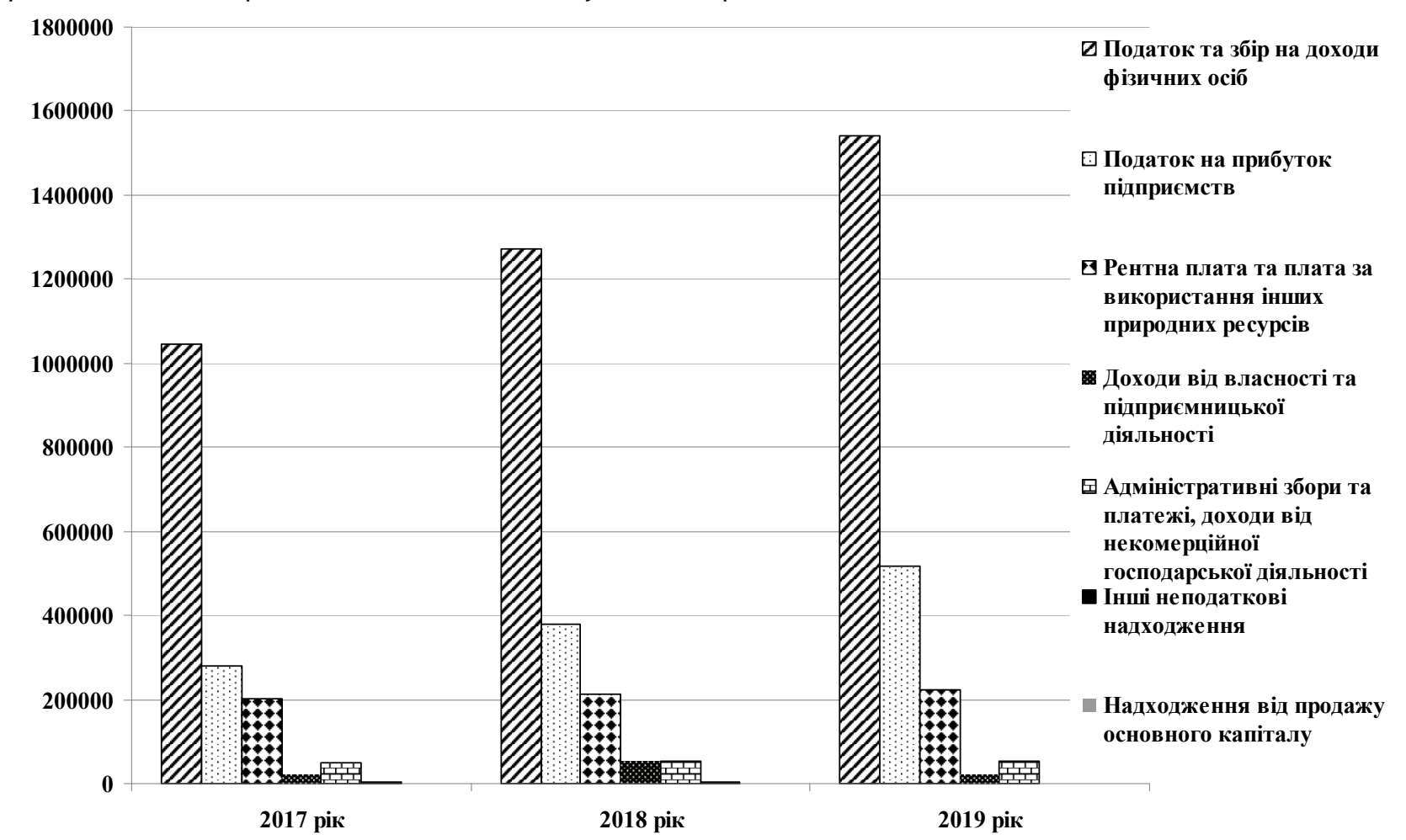

Рис. 1. План і виконання доходів бюджету Запорізької області за 2017-2019 рр., тис. грн лежність місцевої бюджетної системи від волатильності цін на вітчизняному ринку товарів та послуг, підвищити значення довгострокового фрінансового прогнозування доходів і витрат та сорормувати в необхідних обсягах суверенні фонди місцевих бюджетів.

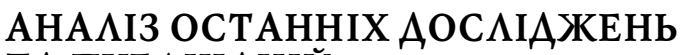

ТА ПУБАІКАЦІЙ

Питання про ефективність фрормування та виконання місцевих бюджетів було висвітлено багатьма вітчизняними дослідниками такими як: Булгакова С.О., Василик О.О., Глущенко В.В., Грузіна І.А., Єфрремова І.І., Кириленко О.П. та багато ін.

Джерело: побудовано авторами на основі [1-3]. 


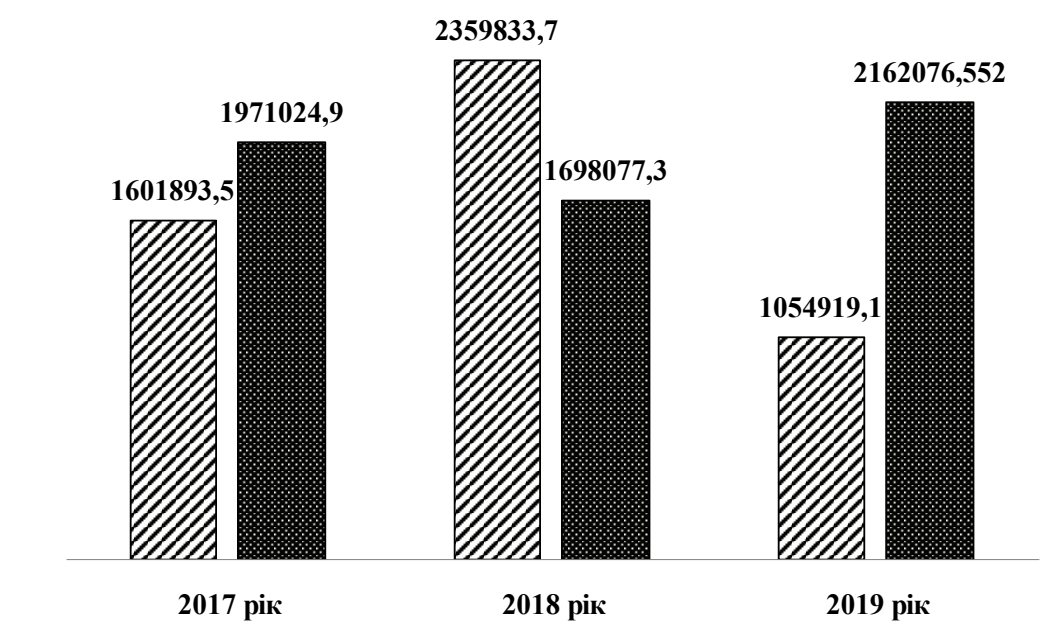

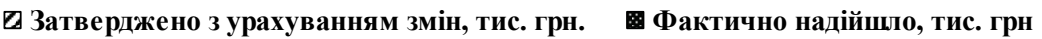

Рис. 2. Динаміка плану і виконання доходів бюджету Запорізької області за 2017-2019 рр.

Джерело: побудовано авторами на основі [1-3].

\section{META CTATTI}

Метою дослідження $€$ аналіз ефективності формування та виконання місцевих бюджетів на прикладі Запорізької області.

\section{ВИК АА ОСНОВНОГО \\ MATEPIA $\Lambda$ У}

Планування доходів бюджету - це важлива складова у системі бюджетного та податкового менеджменту, роль якого до останнього часу було недооцінено як науковцями, так і практиками. Недооцінка процесу планування податків в організації місцевих фінансів та визначенні бюджетних доходів частіше за все призводила до виникнення дисбалансів в податковій політиці і, як наслідок в управлінні бюджетними потоками.

На рисунку 1 представлено планові і фрактичні показники доходів Запорізької області за 2017-2019 pр.

Протягом аналізованого періоду обсяг доходів збільшувався. Так, у 2018 році фрактичне виконання надходження доходів збільшилося на 356841,8 тис. грн, порівняно з 2017 роком. А у 2019 році, порівняно з 2018 роком, фрактичне перевиконання становило 107157,45 тис. грн.
На рисунку 2 представлено динаміку плану і виконання доходів бюджету Запорізької області за 2017$2019 \mathrm{pp}$.

У 2018 році перевиконання затвердженого плану доходів становило 83894,2 тис. грн, або 4,26\%. Збільшення відбулося за рахунок приросту обсягу фрактичних надходжень від податків на прибуток підприємств, а саме на 11,42 порівняно із планом. У 2019 році відбулося недовиконання затвердженого плану доходів і становило $-197757,15$ тис. грн, або -8,38\%. Але в цьому році відбулося і перевиконання деяких статей доходів. Збільшення обсягу фактичних надходжень відбулося за іншими неподатковими надходженнями в 2,6 раз, а саме на 1312,5 тис. грн.

Під час формування бюджету Запорізької області встановлюються ті обсяги доходів, які сформовані розрахунковим шляхом, тобто за основу беруться статистичні показники, планові заходи.

Відповідно до бюджетного кодексу України, бюджет складається на плановий та 2 наступні прогнозні періоди. Основними макроекономічними показниками при складанні бюджету є мінімальна заробітна плата, посадовий оклад працівників, коефіцієнти збільшення ви-

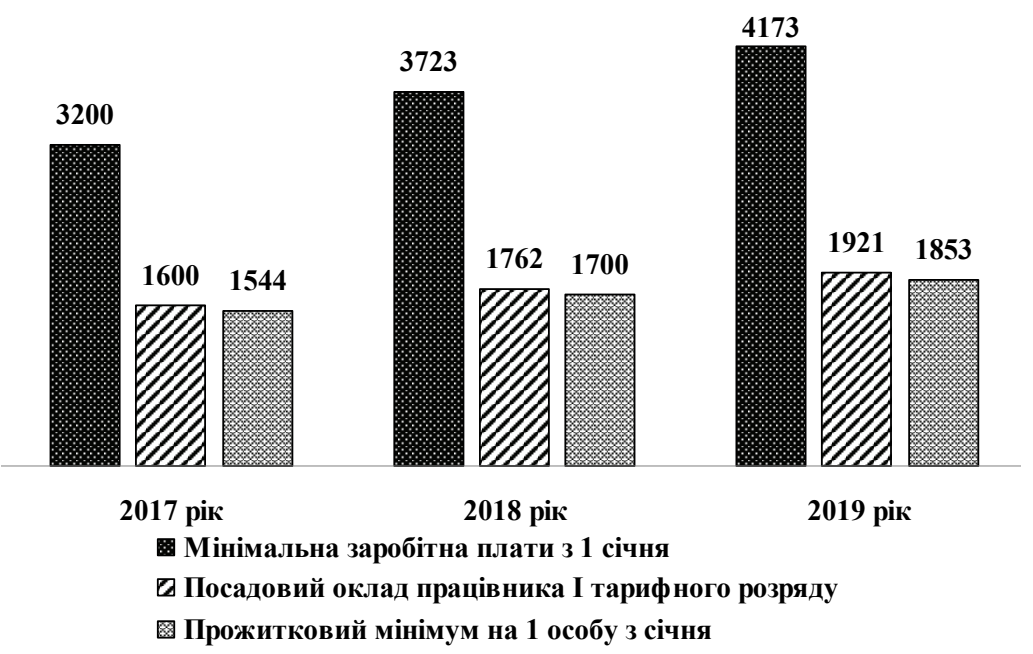

Рис. 3. Динаміка основних макропоказників економічного і соціального розвитку України на 2017-2019 роки 
Таблиця 1. Показники обсягу доходів обласних бюджетів та їх населення

\begin{tabular}{|l|l|l|l|l|l|l|}
\hline \multirow{2}{*}{ Регіон } & \multicolumn{2}{|c|}{2017 рік } & \multicolumn{2}{c|}{2018 рік } & \multicolumn{2}{c|}{2019 рік } \\
\cline { 2 - 7 } & $\begin{array}{c}\text { Обсяг } \\
\text { доходів } \\
\text { бюджету, } \\
\text { тис. грн }\end{array}$ & $\begin{array}{c}\text { Населення, } \\
\text { тис. осіб }\end{array}$ & $\begin{array}{c}\text { Обсяг } \\
\text { доходів } \\
\text { бюджету, } \\
\text { тис. грн }\end{array}$ & $\begin{array}{c}\text { Населення, } \\
\text { тис. осіб } \\
\text { Оосяг } \\
\text { доходів } \\
\text { бюджету, } \\
\text { тис. грн }\end{array}$ & $\begin{array}{c}\text { Населення, } \\
\text { тис. осіб }\end{array}$ \\
\hline $\begin{array}{l}\text { Запорізька } \\
\text { область }\end{array}$ & 2401057,5 & 1723,2 & 2807498,2 & 1705,8 & 2562964,7 & 1687,4 \\
\hline $\begin{array}{l}\text { Житомирська } \\
\text { область }\end{array}$ & 1006016,9 & 1231,2 & 1304624 & 1220,2 & 1391541,5 & 1208,2 \\
\hline $\begin{array}{l}\text { Львівська } \\
\text { область }\end{array}$ & 13309958,8 & 2529,6 & 15101578,6 & 2522,0 & 17652057,2 & 2512,1 \\
\hline $\begin{array}{l}\text { Кіровоградська } \\
\text { область }\end{array}$ & 945100,3 & 956,3 & 978049,7 & 945,5 & 1046447,2 & 933,1 \\
\hline $\begin{array}{l}\text { Харківська } \\
\text { область }\end{array}$ & 15069934,9 & 2694,0 & 18134326,9 & 2675,6 & 20978600,5 & 2658,5 \\
\hline
\end{tabular}

Джерело: побудовано авторами на основі [3-7].

датків та прогнозний індекс споживчих цін. Прогноз основних макропоказників економічного і соціального розвитку України на відповідний період затверджується постановою Кабінету міністрів України.

Протягом 2017-2019 рр. мінімальна заробітна плата збільшилась з 3200 грн до 4173 грн, а саме на 973 грн (+30,4\%). Цей показник використовується при плануванні заробітної плати працівників бюджетної сфери.

Взаємозалежним від нього $є$ нарахування на заробітну плату в розмірі $22 \%$ (рис. 3 ).

Середньодушові доходи населення окремих місцевих бюджетів $є$ головним показником під час здійснення міжбюджетних трансфертів, а саме під час визначення трансфертів відповідному місцевому бюджету. Для аналізу середньодушових доходів місцевих бюджетів по областях України за 2017-2019 роки було обрано такі області, як Запорозька, Житомирська, Львівська, Кіровоградська та Харківська. Такий принцип обрання областей, для проведення аналізу, зможе приблизно охарактеризувати потенціал розвитку окремих регіонів України, а також визначити, які із регіонів України мають найбільші середньодушові доходи, а також рівень залежності від міжбюджетних трансфрертів.

У таблиці 1 представлено основні дані обсягу доходів Запорозької, Житомирської, Львівської, Кіровоградської та Харківської областей, включаючи як власні надходження до загального та спеціального фондів.

Як бачимо, найбільший обсяг доходів у структурі обласного бюджету має саме Харківська область -
1506 9934,9 тис. грн у 2017 році і 20978 600,5 тис. грн у 2019 році, а найменший - 945100,3 тис. грн у 2017 році і 1046 447,2 тис. грн у 2019 році - Кіровоградська область. Варто зазначити, що ці суми не включають обсяги міжбюджетних трансорертів, тобто вони сорормовані за рахунок власних надходжень до відповідних бюджетів, що представлені податковими, неподатковими надходженнями, а також власними надходженнями бюджетних установ та доходів від операцій з капіталом за загальним і спеціальним фондом.

Управління бюджетними коштами є важливою частиною бюджетної політики і в значній мірі визначається станом бюджетного процесу, порядком планування, затвердження і виконання бюджету в частині витрат, а також контролем його виконання. Таким чином, вдосконалення практики бюджетування слід розглядати як важливий інструмент підвищення ефрективності та результативності від державних витрат [8].

Метою державного управління і місцевого самоврядування $€$ зростання рівня і якості життя населення. Забезпечення досягнення цієї мети сприяють: коштів;

- підвищення доцільності витрачання бюджетних

$$
\text { - підвищення результативності витрачання бюд- }
$$
жетних коштів;

- підвищення економічності витрачання бюджетних коштів.

Підвищення доцільності, результативності та економічності витрат бюджету сприяють також зростанню до-

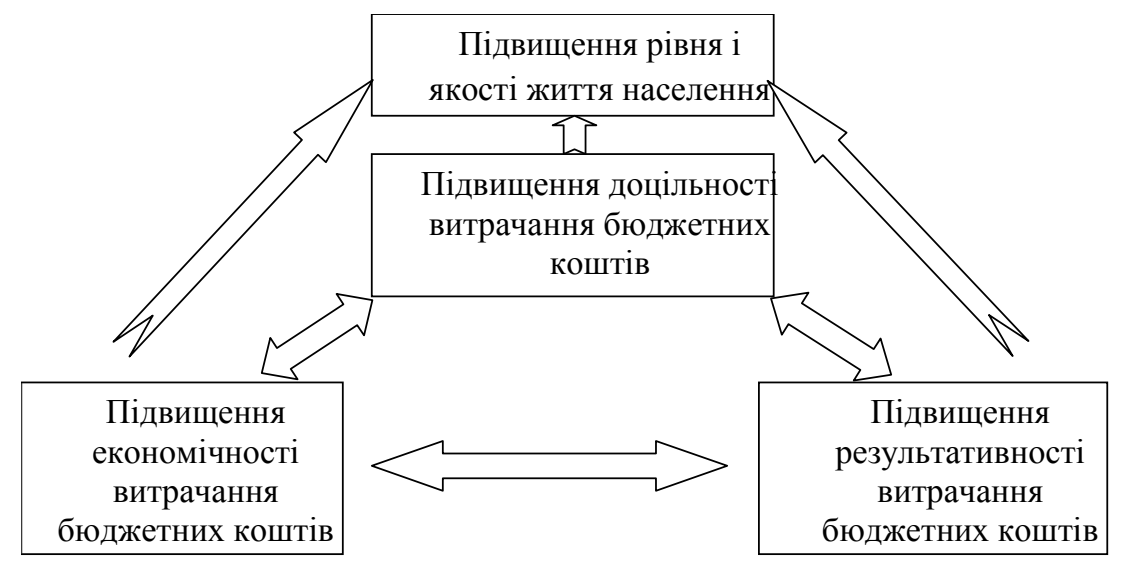

Рис. 4. Досягнення підвищення рівня і якості життя населення 
ходів бюджету як побічно, так і безпосередньо. При цьому зростання доходів бюджету безпосередньо пов'язаний з ростом доходів, рівнем і якістю життя населення і в той же час створює додаткові можливості для здійснення ефективних витрат по підвищенню рівня i якості життя населення (рис. 4).

Підвищення доцільності, результативності та економічності витрачання бюджетних коштів $€$ трьома складовими ефективності управління суспільними фінансами.

Першою складовою оцінки якості управління $є$ визначення доцільності діяльності, спрямованої на вирішення проблеми. Другою складовою оцінки якості управління $€$ аналіз результативності. Для оцінки показника результативності необхідною умовою $€$ наявність кількісного опису поставленої мети і вимірності значення результату певної діяльності. Третьою складовою оцінки якості управління $\epsilon$ аналіз показника економічності, тобто співвідношення результату до витрат.

Основні заходи по підвищенню ефективності бюджетних витрат і їх вплив на складові ефективності бюджетних витрат:

1. Комплексний аудит бюджетних видатків, спрямований на визначення можливостей підвищення їх ефективності. Захід $€$ настановним за визначенням ефективності бюджетних витрат. Результатом реалізації заходу $є$ збільшення ефективності здійснюваних в даний момент бюджетних витрат.

2. Розширення практики застосування методів бюджетування, орієнтованого на результат у сферах виробництва державних послуг, де такі методи впроваджені не повною мірою і вдосконалення зазначених методів. Результативність: розробляється система збалансованих показників, спрямована на контроль досягнення цілей, вирішення завдань і виконання заходів, а також система процедур з контролю значень цих показників.

3. Удосконалення системи управління та підвищення ефективності бюджетних витрат за допомогою аналізу, порівняння та інтеграції механізмів бюджетування, орієнтованого на результат [9, с. 36].

4. Удосконалення системи планування діяльності виконавчих органів державної влади з метою надання їй цільового характеру, контролю досягнення результатів діяльності, фрормування системи стимулювання державних службовців з урахуванням результатів їх професійної службової діяльності. Результативність: вдосконалення системи планування передбачає закріплення за кожним працівником системи показників діяльності, а також контроль планування та досягнення встановлених значень показників, прив'язку системи стимулювання до системи показників.

5. Удосконалення системи розподілу всіх видів бюджетної допомоги: субсидій, субвенцій, дотацій, бюджетних кредитів. Підвищення ефективності видів бюджетної допомоги шляхом системної оцінки їх цілей.

6. Створення типової моделі муніципального управління. Створення типової моделі муніципального управління дозволить органам місцевого самоврядування підвищити доцільність діяльності муніципальних утворень, прийняти обгрунтоване рішення про звільнення або подальше фрінансування надлишкових функцій, порівняти і оцінити результативність і економічність з ти- повими показниками результативності та економічності, збільшити оперативність поширення найбільш економічних варіантів організаційних форм та знизити витрати на підтримку в актуальному стані системи повноважень, функцій і послуг, тобто підвищити економічність.

7. Удосконалення системи наповнення бюджету, підвищення ефективності надання податкових пільг, збирання податків.

Під час розроблення зазначених моделей буде розглядатися ефективність кожного з використовуваних механізмів системи наповнення бюджету за тимиж параметрами, за якими оцінюється ефективність витрачання бюджетних коштів.

Основним інструментом підвищення ефективності бюджетних витрат як складової частини ефективності діяльності органів державної влади та органів місцевого самоврядування пропонується вдосконалити програмно-цільовий принцип організації їх діяльності.

Для реалізації зазначених підходів необхідно:

1) удосконалювати порядок розробки, реалізації та оцінки ефективності цільових програм;

2) визначити перелік цільових програм і розвивати застосування програмно-цільових інструментів реалізації бюджетної політики;

3) визначити порядок планування обсягів бюджетних асигнувань бюджету на реалізацію цільових програм з урахуванням необхідності ув' язки з бюджетним процесом.

Впровадження програмно-цільового принципу організації діяльності виконавчих органів державної влади і необхідність створення умов для планування бюджетних асигнувань за новими принципами вимагають зміни процесу складання і затвердження бюджету.

3 метою підвищення ефективності програмного управління діючі регіональні та муніципальні положення про розробку та реалізацію цільових програм пропонується доповнити оцінкою їх впливу на показники економічного і соціального розвитку відповідної території, що відображають рівень і якість життя населення.

\section{ВИСНОВКИ}

Отже, місцеві бюджети відіграють важливу роль у сорері публічних фрінансів, які охоплюють економічні відносини стосовно того, що місцеві органи управління мобілізують розподіляють і використовують відповідно до покладених на них функції частину суспільного продукту в грошовій формі. Бюджетні відносини виконують особливе призначення - розподіляють валовий внутрішній продукт, доходи від зовнішньоекономічної діяльності і частина національного багатства з метою надання органам державної влади та органам місцевого самоврядування фрінансових ресурсів. При цьому фрінансові ресурси, якіє матеріальними носіями бюджетних відносин, формуються і використовуються у формі фондів грошових коштів, створюваних відповідними органами влади або органами місцевого самоврядування та використовуваних ними для задоволення суспільних потреб.

\section{Література:}

1. Інформація департаменту фрінансів Запорізької обласної державної адміністрації про виконання облас- 
ного бюджету за 2017 рік. URL: https://www.zoda.gov.ua/news/39616/informatsiya-departamentufinansiv-zaporizkoji-oblasnoji-derzhavnoji-administratsiji--pro--vikonannya--oblasnogo--bjudzhetu--za-2017rik.html (дата звернення 02.02.2021).

2. Інформація департаменту фінансів Запорізької обласної державної адміністрації про виконання обласного бюджету за 2018 рік. URL: https://www.zoda.gov.ua/news / 44829/publichne-predstavlennyainformatsiji-pro-vikonannya-oblasnogo-bjudzhetu-za2018-rik.html (дата звернення 02.02.2021).

3. Інфрормація департаменту фрінансів Запорізької обласної державної адміністрації про виконання обласного бюджету за 2019 рік. URL: https://www.zoda.gov.ua/news /49150/informatsiya-departamentufinansiv-zaporizkoji-oblasnoji-derzhavnoji-administratsiji-pro-vikonannya-oblasnogo-bjudzhetu-za-2019rik.html (дата звернення 02.02.2021).

4. Інформація про виконання бюджету Житомирської області за 2017-2019 роки. URL: https://zt.gov.ua/index.php/zhitomirshchina/pro-nash-kraj/oblasnijbyudzhet.html?start=115 (дата звернення 02.02.2021).

5. Інформація про виконання бюджету Кіровоградської області за 2017-2019 роки. URL: https:// oblrada.kr.ua/informatsiya-pro-oblasnij-byudzhet (дата звернення 02.02.2021).

6. Інформація про виконання бюджету Львівської області за 2017-2019 роки. URL: https://loda.gov.ua / zvit_pro_vykonannya_byudzhetu_oblasti (дата звернення 02.02.2021).

7. Інформація про виконання бюджету Харківської області за 2017-2019 роки. URL: https: / /loda.gov.ua / zvit_pro_vykonannya_byudzhetu_oblasti (дата звернення 02.02.2021).

8. Бюджетний моніторинг: аналіз виконання Державного бюджету України 2016. URL: http://www.ibser.org.ua/sites/default/files/kv_iv_2016_monitoring_ukr_0.pdf (дата звернення 02.02.2021).

9. Станкус Т. Програмно-цільовий метод у бюджетному процесі на рівні місцевих бюджетів / Т. Станкус. Х.: Фактор, 2017. 128 с.

\section{References:}

1. The official site of the Zaporizhia Regional State Administration (2017), "Information of the Department of Finance of the Zaporizhia Regional State Administration on the implementation of the regional budget for 2017", available at: https://www.zoda.gov.ua/news/39616/ informatsiya-departamentu-finansiv-zaporizkojioblasnoji-derzhavnoji-administratsiji--pro-vikonannyaoblasnogo-bjudzhetu-za-2017-rik.html (Accessed 2 February 2021).

2. The official site of the Zaporizhia Regional State Administration (2018), "Information of the Department of Finance of the Zaporizhia Regional State Administration on the implementation of the regional budget for 2018", available at: https://www.zoda.gov.ua/news/44829/ publichne-predstavlennya-informatsiji-pro-vikonannyaoblasnogo-bjudzhetu-za-2018-rik.html (Accessed 2 February 2021).

3. The official site of the Zaporizhia Regional State Administration (2019), "Information of the Department of
Finance of the Zaporizhia Regional State Administration on the implementation of the regional budget for 2019", available at: https://www.zoda.gov.ua/news/49150/ informatsiya-departamentu-finansiv-zaporizkojioblasnoji-derzhavnoji-administratsiji-pro-vikonannyaoblasnogo-bjudzhetu-za-2019-rik.html (Accessed 2 February 2021).

4. Official website of the Zhytomyr Regional Council (2019), "Information on the implementation of the budget of the Zhytomyr region for 2017-2019", available at: https://zt.gov.ua/index.php/zhitomirshchina/pronash-kraj/oblasnij-byudzhet.html?Start=115 (Accessed 2 February 2021).

5. Official site of Kirovograd regional for the sake of (2019), "Information on the execution of the budget of the Kirovohrad region for 2017-2019", available at: https:/ /oblrada.kr.ua/informatsiya-pro-oblasnij-byudzhet (Accessed 2 February 2021).

6. Official site of the Lviv Regional State Administration (2019), "Information on the execution of the budget of the Lviv region for 2017 - 2019", available at: https:/ / loda.gov.ua/zvit_pro_vykonannya_byudzhetu_oblasti (Accessed 2 February 2021).

7. Official site of Kharkiv region (2019), "Information on the implementation of the budget of the Kharkiv region for 2017-2019", available at: https://loda.gov.ua/ zvit_pro_vykonannya_byudzhetu_oblasti (Accessed 2 February 2021).

8. Official site of annual report on the execution of the State Budget of Ukraine (2016), "Budget monitoring: analysis of the implementation of the State Budget of Ukraine 2016", available at: http://www.ibser.org.ua/ sites/default/files/kv_iv_2016_monitoring_ukr_0.pdf (Accessed 2 February $2 \overline{0} 2 \overline{1}$ ).

9. Stankus, T. (2017), Prohramno-tsil'ovyj metod u biudzhetnomu protsesi na rivni mistsevykh biudzhetiv [Program-target method in the budget process at the level of local budgets], Factor, Kharkiv, Ukraine.

Стаття надійшла до редакиї 24.02.2021 p.

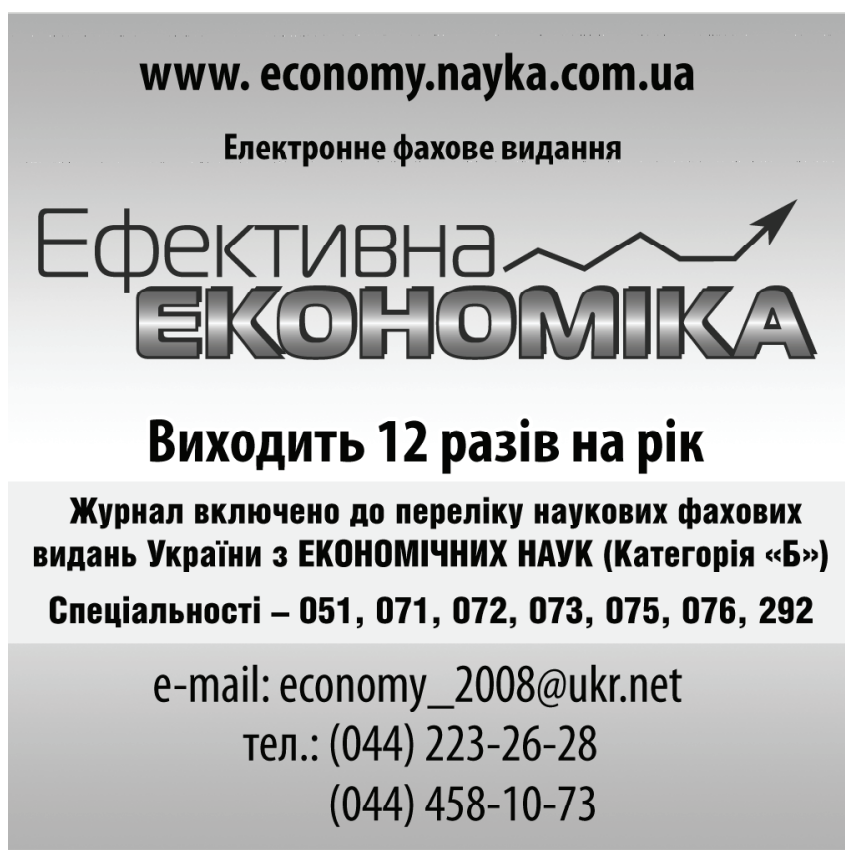

